UDC 130.2

LBC 87.6

\title{
COVID-19 AND POLYGLOT PEACE: A GRAMMATICAL UNDERSTANDING OF OUR PRESENT PREDICAMENT
}

\author{
O. Kroesen
}

Delft University of Technology, Delft, Netherland

\begin{abstract}
The challenge of the COVID-19 pandemic, it is argued in this contribution, can only be met by a common effort of responsibility by all nation states across the world. That is what the COVID-19 pandemic has in common with the upcoming climate crisis and with the social and economic problems of the emerging world society in general. This contribution, however, is not focused on direct and effective methods and solutions. Such measures and methods can only meet their objectives within the framework of a new understanding. It requires a new way of ordering the world, a new type of man, a new way of speaking with and to each other. Anew mindset and attitude are required. This, it is proposed, will be a mindset shaped by the grammatical method or, more commonly called, the dialogical philosophy of Rosenstock-Huessy and a circle of friends. It is the aim of the grammatical method to find the right rhythm, sequence and alternation of the different values and institutions of different societies and cultures. This can put the analytical methods and measures for the COVID-19 crisis within the broader framework of a history of salvation. We have to understand where each of our traditions is coming from, and how we are challenged to find a common destination. The COVID-19 crisis turns such mutual understanding and a sense of common purpose into a true imperative. Therefore the potential of the grammatical method to meet that requirement is explored with a special focus on the understanding of language by Rosenstock-Huessy and Levinas.
\end{abstract}

Key words: COVID-19 pandemic, language, grammatical method, dialogue, history of salvation, world wars, planetary life.

Citation. Kroesen O. COVID-19 and Polyglot Peace: A Grammatical Understanding of Our Present Predicament. Logos et Praxis, 2021, vol. 20, no. 2, pp. 15-24. DOI: https://doi.org/10.15688/lp.jvolsu.2021.2.2

УДК 130.2

ББК 87.6

\section{COVID-19 И МНОГОЯЗЫЧНЫЙ МИР: ГРАММАТИЧЕСКОЕ ПОНИМАНИЕ НАШЕГО НЫНЕШНЕГО ЗАТРУДНИТЕЛЬНОГО ПОЛОЖЕНИЯ}

\author{
Отто Кройзен \\ Делфтский технологический университет, г. Делфт, Нидерланды
}

\begin{abstract}
Аннотация. В статье утверждается, что проблема распространения коронавирусной инфекции может быть решена только общемировыми усилиями всех национальных государств. Это сближает пандемию COVID-19 c климатическим кризисом, с социальными и экономическими трудностями перед формирующимся мировым сообществом. Однако цель статьи состоит не в том, чтобы предложить прямые и эффективные методы решения проблемы. Это возможно только в рамках нового понимания ситуации, что требует нового способа упорядочения мира, нового типа человека, нового способа говорить друг с другом, нового мышления и отношения. Предполагается, что это будет мышление, сформированное грамматическим методом, или, как его чаще называют, диалогической философией Розенштока-Хюсси и круга его единомышленников. Цель грамматического метода состоит в том, чтобы найти правильный ритм, последовательность и чередование различных ценностей и институтов разных обществ и культур. Это позволяет рассматривать аналитические ष्. методы и меры для преодоления кризиса COVID-19 в более широких рамках истории спасения. Человечеству необходимо понять истоки своих культурных традиций и на этом основании сформулировать свое общее ()) предназначение. Кризис COVID-19 превращает такое взаимопонимание и чувство общей цели в истинный
\end{abstract}




\section{ИЗОЛЯЩИЯ В ОТКРЫТОМ ОБЩЕСТВЕ}

императив. Потенциал грамматического метода, призванного решить эти задачи, исследуется на примере философско-лингвистических концепций О. Розенштока-Хюсси и Э. Левинаса.

Ключевые слова: пандемия COVID-19, язык, грамматический метод, диалог, история спасения, мировые войны, планетарная жизнь.

Цитирование. Кройзен O. COVID-19 и многоязычный мир: грамматическое понимание нашего нынешнего затруднительного положения // Logos et Praxis. - 2021. - Т. 20, № 2. - C. 15-24. - (На англ. яз.). - DOI: https://doi.org/10.15688/lp.jvolsu.2021.2.2

\section{Introduction}

The COVID-19 pandemic is one of the birth pains of the movement towards one global society. We are in the midst of a social revolution that turns nation states and power blocs into parts of one global society. Such a global society is the minimum requirement to meet the challenges of our era, poverty, climate change, mass extinction, violence. But each social revolution, in order to succeed, needs a new language, a new discourse. This new language has emerged during and after the world wars. In essence the world wars are the world revolution, because they mobilized even the remotest parts of the world and they left humanity with the one certainty that it has to live together lest it destroys itself.

It is striking that the language theory of Rosenstock-Huessy came as a response to the first world war, where nations took themselves as absolutes, and that the language theory of Levinas came as a response to the second world war and its atrocities. The message was the same: responsibility for a common future. A better word would even be "responsiveness". Both of them came up with the idea that the core of our existence is not self-identity, but substitution (Levinas) or transubstantiation (Rosenstock-Huessy). Speech as relation to the other becomes more central than thinking.

Our present day politicians and policies do not yet meet that standard. The COVID-19 pandemic does not only isolate us from each other, but also makes most of our politicians grapple for resources to serve their own constituency. But like with climate change the COVID-19 crisis cannot be solved on a national basis. So our politicians cannot avoid it: they have to talk instead of fight.

\section{A strange thing about the diary of Anne Frank}

The diary of Anne Frank has become a famous document from the second world war the world over. It is a diary of a Jewish young girl who had to hide with her family for two years during the German occupation. In 1944 the family was betrayed and apprehended. Anne Frank died in 1944 in Bergen Belsen from typhus. The diary has been translated in 70 languages. Why has it become so popular? The war only appears at the horizon of the book, as its background. The theme of the book is about eight people who had to live together and cope with each other in a too small space. That very well represents the postwar situation of the emerging global society [Leenman 2016]. That is the situation the world wars have brought us into. On a subconscious level that may explain the popularity of the diary. The prospect and the difficulty of living together in a too small space and having to cope with each other despite all differences and conflicts, is precisely the worldwide situation created by the world wars.

The emerging worldwide society is not orchestrated by a central state and having a central state wouldn't even be desirable despite the worldwide cooperation required. This world society has no center and that precisely is the difference between having a state and having a society. A society consists of a multiplicity of centers. Many stakeholders pursuing their own interests and nevertheless have to deal with each other. They do not always like each other, or trust each other, but they are stuck with each other in this small world. They have to negotiate, they have to talk. They have to listen, whether they like it or not. They have to make room for each other in order to make room for a common future. The small society of eight people in the book of Anne Frank mirrors the worldwide predicament we find ourselves in.

\section{The world wars as world revolution}

The world wars brought us into this predicament. They made it impossible for even the smallest state to turn its back to the rest of 
world society. They were the unavoidable outcome of European economic competition and imperialism. They were not only predicted by Karl Marx, but also by Friedrich Nietzsche. The scramble for Africa since 1870, the process of European imperialism subjecting more and more colonies to the European nations, and the emergence of Germany as a central state uniting the different German principalities, are part of it [Winkler 2009]. New technologies were introduced and large-scale production by big investments took off. The European nations took themselves as absolutes and treated each other as external objects, external markets and competitors [Rosenstock-Huessy 1993]. The nations that went to war all suffered from a superiority complex: they estimated it would be a short conflict in which their own forces would easily prevail. They underestimated their enemies. This attitude is related to the prevailing philosophy of the subject with its rationality. For the rational subject everything outside becomes an object. At the level of individual companies this brings a focus on production dealing with everything, workers, materials, a means to reach that goal [RosenstockHuessy 1926]. At the level of national politics this meant that one's nations habits came to be understood as logical and rational and values and habits of different nations were considered as inferior and decadent. At the same time the economy globalized and technology unified the world. As a consequence the age of reason stumbled into the most irrational power conflict the world had ever seen.

\section{Beyond the dialectics}

\section{of the French and the Russian Revolutions}

Was the scientific socialism of the Russian Revolution than the better solution? The aim was not to leave production and distribution in the hands of individual companies but avoid externalization of costs on the workers and on nature by having all control in the hands of a rationally administrated central government. Five year plans replaced the market, ruthlessly moving people and production materials around in the newly established Soviet Union. And true, during the crisis of 1929 the Soviet Union did not suffer the economic setbacks of the Western nations. Since the second world war some form of central planning of the economy has become part of the policies of every nation state. However, the dialectics between the French and Russian Revolution cannot hide the fact that both originated from the monolog of reason and logic. Therefore the question remains whether the five-year plan really was the new language of an emerging global society.

\section{The discovery of language}

\section{by Rosenstock-Huessy and a circle of friends}

When the first world war broke out Eugen Rosenstock-Huessy was already teaching as a so-called Privatdozent at the University of Leipzig since 1912. He was born of Jewish parents in 1888 although his parents lived according to the Christian calendar, so that he once stated he became spiritually awake as a Christian. In the middle of the war he had his vision of European history that would later (1931) lead to his book on European history, Die Europäischen Revolutionen; Volkscharaktere und Staatenbildung [Rosenstock-Huessy 1989]. While the European nations were tearing each other apart the vision of European history dawning to him in the trenches of Verdun entailed that the European revolutions which had emerged in the respective nations of Europe actually were part of a dialogue. In creating and developing their different national characters the European nations reacted on each other and build further on each other. That dialogue was the essence of European history. The next revolution sets right the achievements of former ones, after its original innovation and inspiration has become obsolete and petrified. Each time unarticulated parts of our human character are rediscovered and are assigned a more central place and receive a more pronounced expression. Each time a new human type emerges together with a new order of law and a new language. These human types with their ways of speech and codes of behavior, values and inspirations now have to live together by mutual interpenetration, by finding the right alternation of their different values and ways of life.

In this interpretation of history language is put at the forefront. Rosenstock-Huessy was already for a longer time interested in language. In his exchange of letters with his friend Rosenzweig, Rosenzweig asked him at one moment his opinion about the meaning of 
languages. This led to a lengthy letter, from 1916, which later became the heart of the brochure Angwandte Seelenkunde, published in 1923 [Rosenstock-Huessy 1963]. It also became the methodological basis of the Stern der Erlösung, the later main work of Rosenzweig, published in 1921 [Rosenzweig 1976]. In both works it is the imperative of a new love that commands a new marching order both in personal life and in history. Such a new marching order implies a rupture in the natural course of events. As a consequence human life and history breaks in two halfs. I have to go beyond my past. It is my soul that is already at the other shore. The new love calls for obedience and courage. The war itself in its meaning was such a new imperative. It called for other commitments than they had before. Rosenstock-Huessy had prepared himself for becoming a scientist of history and language, a real German professor. He now became the first editor of the first factory newspaper of Germany at Daimler-Benz. After the war he couldn't continue his scientific career just like that. He saw how in the turmoil of the national crisis, of labor and industry, the German people was losing its direction and orientation. By means of this factory newspaper and later by organizing work camps with participants from all walks of life he tried not to communicate some or other conviction, but to create mutual understanding in view of a future to come. Challenging, discussing, and involving professors and priests and jobless and students in those discussions, he tried to create a basis of communication and understanding. In this approach language is not in the first place the vehicle for communication, but a means of creating trust and of opening up. A new spirit was becoming awake in those work camps.

The work camps as well as the factory newspaper helped people to grow in their capacity to speak. It helped to replace the most natural reaction towards the fragmentation and mechanization both of the factory system and the war experience. In the understanding of Rosenstock-Huessy the proletarization of the workers did not so much consist in too low wages but much more in their instrumentalization. Paid by the day or the hour, or per week, being of value merely by the work of their hands, that is what robbed them of their time perspective and of their belongingness and that is what made them uprooted. This uprootedness was the problem of the population of Germany in general after the first world war [Rosenstock-Huessy 1920]. It had become impossible to identify with some larger history, say the mission of the German Empire, or whatever could provide a lasting identity. All those options had lost their credibility. The most natural reaction to this uprootedness is and has always been to cling all kinds of mythical collectivisms. Socialism and communism as well provided the workers with a collective identity. This made these movements attractive for the workers more than low wages. In a situation of uprootedness these collectivisms created artificial identities, like later also fascism and National Socialism did. In the work camps, however, the collective labor provided the experiential basis of mutual recognition. By exchanging opinions and taking people seriously as adults, by inviting professors and other speakers as participants in the ongoing discussion and not so much as people who know all and everything, workers were challenged to think and judge of their own and to exercise a more independent judgment. It was this capacity to listen and speak and take responsibility that Rosenstock-Huessy wanted to foster.

\section{The grammatical method}

These circumstances need to be highlighted so that the reader understands the experiential basis of the grammatical method of RosenstockHuessy. The grammatical method was not just another theoretical tool. Instead, RosenstockHuessy accurately followed the grammatical order of his own experiences. He theorized what he went through himself. He already summarized his grammatical method in his Soziologie of 1926 (later completed and published in 1956 and 1958). It is called grammatical, because the moods of grammar play a decisive role in it. The imperative mood is expressed by the formula $1=1$, meaning that in relation to the realization of a new imperative lonely individuals are at the forefront. They break away from the existing group and have the courage to start something new. The existing group, the collective, like a trade union or a political party that provides identity, is expressed by the, meaning that an indefinite number of people identifies with some idea or utopia or any other collective understanding. This is the participative 
mood of language, the participation in a common history. In the tension between imperative mood and participative mood individuals should grow towards having their own judgment and having an adult exchange of insights and opinions. This is the conjunctive mood, because in open discussion and debate people are conjugated to each other by proposals and counterproposals. Also insights marry with each other. That means they can be valued besides each other and contribute to each other, fine-tune each other: $2=1$. Finally the labor group, the team at the shopfloor, represents the indicative mood. The shared experience of managing their own daily affairs creates a basis of mutual recognition and growth in responsibility. This is expressed by the formula $3=1$, where the number 3 can also be replaced by any other number of workers sharing their daily work as a team.

Rosenstock-Huessy called this fourfold alternation of grammatical moods the cross of reality. By this term he expresses the fact that the alternation, the capacity of saying no to one's fixed identity, is the way of taking up the cross of Christ in the present predicament. The real paganism in our time is the refusal to change by the refusal to respond. "People have to accept me as I am" that is paganism. For this so-called cross of reality Rosenstock-Huessy also used the sentence "respondeo etsi mutabor", I respond although that brings a change [Rosenstock-Huessy 1970]. At the core of my identity, I do not merely identify with myself, but my future destination is calling upon me. I continuously have to stop with that what I am good at and I have to change and adopt correction and integrate different contributions. In this way ultimately my identity is created. In this way the imperatives of the past that haven't been dealt with sufficiently keep calling upon me as well and this call from the past together with the call from future "make" my identity. Actually my identity is a process in transition. In fact there is no selfidentity. By the response that I cannot avoid, stepby-step my identity is created. Rosenstock-Huessy also calls this process transubstantiation, because the new generation is constantly evoked anew both by the calls from the past and the destination from the future, and these are the substance of my being, my substance consisting in my response. I am not filled by my own substance. I am as it were a verse in a larger poem.
His friend Rosenzweig absorbed and accepted all these insights on language, but he insisted on the eternal meaning of the voice of Judaism, the people by which the imperative mood was revealed for the first time in its full weight, as in the Jewish Bible and in the Jewish tradition. In its feasts, liturgy, traditions, and its understanding and the practice of the Torah the Jewish people provide the one and lasting incarnation of the imperative for a final and definite justice and peace at the end of history. If it is the Christian mission to change history step-by-step by endorsing time and again new imperatives and realizing them in a process of revolutionary changes the Jews have a different mission. The Christian mission can only be understood as radiation that comes from the Jewish mission, which is to maintain the fire itself where the light comes from. It is Israel that lives in the heat of the fire in its loyalty to the Torah, in its living as a lasting people. This lasting voice of Israel, Rosenzweig felt, is what he should join and express. That is also the message of his Stern der Erlösung. That also explains his new practice after its publication. He started the Freies Jüdisches Lehrhaus in 1920 in Frankfurt with the aim to teach Judaism in a more self-conscious way.

Within the circle of friends contributing the new approach involving names like Buber, Von Weizsäcker, Michel, one more name should be singled out in this context, that is Hans Ehrenberg. In 1920 he published a book with the title Die Heimkehr des Ketzers: the time had come that the divisions of the past should become the contributions as of now [Ehrenberg 1920]. The German word Ketzer refers back to the Greek "haeresis" which actually means that a group of people adopts part of the truth, claiming that their part of the truth is the complete truth. He also published texts from Russian philosophers with the title Östliches Christentum, in which he made the Christian Orthodox understanding of reality accessible for Western readers. In Dostoevsky and Tolstoy he considered the time to have come for Russian orthodoxy to open up to the west. The Russian orthodox tradition has shown that in the midst of harsh circumstances there is always in a miraculous way room for heroic deeds of gratuitous love. Where in the West the Christian mission might be understood as a process to reorganize society, the Christian orthodoxy of 
Russia doesn't organize, but one does help a family through the winter with a sack of potatoes. Sparks of mercy lighten in the dark.

\section{The rediscovery of language by Levinas}

The discovery of living speech of Rosenstock-Huessy and his circle of friends was characterized by a sudden breakthrough and then a gradual effectuation until the reception process broke off in 1933, with the coming to power of Hitler. In the case of Levinas it was the other way around. In a gradual process of growth and continuous rephrasing he came to an ever deeper understanding of language. Born in 1906 in Lithuania he witnessed the Russian Revolution from close by in 1917. Probably he had similar high expectations as many other Russian Jews. Later he studied with Husserl from 1923 in Germany, Strasbourg, where he also met Heidegger whose philosophy greatly impressed him but from whom he also took a distance. His book of 1961 Totalité et Infini can be considered an ethical alternative for the philosophy of Heidegger [Levinas 1961]. His constant accusation to Heidegger was not in the first place that he joined National Socialism, but that his philosophy neutralized human existence, by which he means: he replaced first impressions by general descriptions. Everything becomes neutralized by an intellectual gaze and an intellectual distance towards it, even if whatever ethical considerations may still be present. Levinas is going in the opposite direction: the moral relationship with the other, in the human face, confronts me, appeals to me, agitates me, makes me even the hostage of the commandment of responsibility towards the other human being. It is exposure, more direct than any reflection, more light than the eye can bear, not objectifiable - these are the metaphors in which he describes the urgency of responsibility. The word infinity underlines it. There is no measure. It is overwhelming. It is a command, it creates an asymmetry between me and the other as if the other appears (the term epiphany is used!) from on high.

A decisive influence on Levinas is from Rosenzweig, who is too often present in his work to be cited, as he states. After the second world war Christianity cannot be a seduction for the Jews any more, he notes [Levinas 1963]. On the other hand Levinas doesn't want his philosophy to be understood as an exclusively Jewish philosophy. It is philosophy. And it should be criticized and understood as such. Nevertheless, like Rosenzweig, he wants to provide a philosophical expression of the Jewish experience of life. And where Rosenzweig uses the term love for the imperative mood, and even speaks of a command to love, Levinas rather prefers the more dry term responsibility or responsiveness. It is not the case that the imperatives of language replace critical and systematic thinking, but the order is from impression to reflection. The idea of infinity, concrete in the human face that challenges me to be responsible, triggers my finite thoughts. It makes me think. I have to answer.

In two important respects the expressions used in his 1973 work Autrement qu'être, où au delà de l'essence, are more pronounced when it comes to language than comes forward from his former work. First in this work he differentiates between (French) dit (the said) and dire (to say). Living speech is always more than what is said. What has been said can afterwards be systematized and reflected upon, and objectified. But the speech act itself is an act of living responsibility, always ahead of reflection. The act of responsibility is in living speech and the system of language itself is a secondary development. Afterwards, reflecting on living speech (dire), I may become aware of what precisely I said as an objective statement (dit). Life is always more. One is not above it but in it. The other important notion, connected to this, is substitution. Always a word refers to another word, expressions implicate and evoke each other. When we equal $\mathrm{A}=\mathrm{B}$, to an extent at least A can function as a replacement, a substitution for $\mathrm{B}$; by $\mathrm{A}$ I understand B. But in its core speaking is itself also substitution: being-for-the-other. It is my essence as a living creature and as human being to be that reference to the other in the core of my existence. Being human is substitution by me for the other, not by choice, but essentially. That doesn't mean that being human only consists of bearing responsibility and that there is no joy and enjoyment. But, also enjoying the food, enjoying the weather and the elements, is already a typically human joy: it assumes peace established, responsibility taken. Otherwise it becomes subhuman, a refusal of responsibility, mixed with fear. 


\section{Influence of the Russian tradition of Levinas' understanding of language}

Although it is often stated that the philosophy of Levinas is essentially Jewish, there is also reason to argue for other influences. Speaking of substitution and even using terms for it like expiation and atonement reminds of the Christian tradition. A Jewish friend of Levinas Jankйlйvitch, became a Christian, and wrote about Christian themes like forgiveness, but that doesn't hinder Levinas in still calling him a Jew in his way of expressing and behaving [Levinas 1963]. Attempts of interviewers to bring to his attention the value of the Christian tradition and explaining the Christian convictions of the interviewers, fail due to his reaction that he doesn't need the Christian contribution to get the same result. Substitution is for him as Jewish as it may be Christian for others. In another respect he may be more Jewish, in that he doesn't pay much attention and has not much confidence in history as a process of growth. He points to the Holocaust to underline the fragility of such growth.

The spirit of Russian orthodoxy may be present in his work as well. When he describes the human face as miserable in essence, arguing that in the other human being we are essentially confronted with human suffering and a call for responsibility, aren't we then in the sphere of Tolstoy and Dostoevsky? On top of that, isn't responsibility for "essential misery" also an expression of gratuitous love without any system or organization? Levinas doesn't seem to trust these systems of salvation of history very much, just like Russian orthodoxy doesn't. Systems of salvation are always on the verge of turning into their opposite. On the one hand we need institutions for protection of human rights and justice, but on the other hand these systems of justice fail to respond to the human face before us in an act of unique responsibility. Soon we will become subject to the rules of those institutions, which then take away responsibility from us [Levinas 1973]. Always in any system of justice some third person is left out. Always someone knocks at the door in order to be let in. But in that criticism, one might ask, does he express his Jewish sense of justice, or also the Russian orthodox conviction that true love cannot be organized?

\section{Rosenstock-Huessy's understanding of the European heritage and polyglot peace}

Perhaps Levinas' thinking about institutions and social systems is also influenced by the Russian Revolution. His focus on inclusion or exclusion in the rules and regulations does in any case not focus on the human characteristics, values, the human types, mindsets and qualities incorporated in one or other social system. One of the main characteristics of the social system of the Soviet Union was central planning in order to serve the material needs of the masses. Cool calculation and planning have become more articulated and pronounced as legitimate values due to the Russian Revolution. But all the European nations are characterized by a specific set of human qualities that make their systems work. Each and every European revolution succeeded by producing a different set of human qualities and types. Since these human qualities were successful in a time of crisis they became part of the methods for the management of the daily affairs as well. Rosenstock-Huessy distinguishes at least seven of such social upheavals together with the mindsets developing from them.

The papal revolution: during the struggle for investiture (the nomination of bishops) which started in 1076 the Pope claimed authority above the Emperor, although he didn't have physical or military power at his disposal. He always had to move different actors by means of diplomacy and the spiritual authority derived from his office. But throughout Europe laypeople and spiritual people alike came to recognize his authority. During that revolution the spiritual character of his authority was articulated more emphatically and people from high to low learned to distinguish between worldly power and spiritual authority. Authority itself as a human quality in the process became a more spiritual thing.

The city revolution: in the struggle between Pope and Emperor, especially during the $12^{\text {th }}$ century, fraternities, guilds and city councils took the initiative to organize themselves from the bottom up. Formerly organizations like guilds would always have been kept in check by the imperial power. But now guilds and fraternities started to claim jurisdiction for themselves, they made their members take an oath on the laws and regulations, 
often under the leadership of the mendicant orders which supported them. They built walls around the cities and negotiated with the nobility with or without some fighting for their independence. In the course of this revolution they developed more civil behavior, as a first step of creating trust and cooperation beyond family loyalties of a clannish or tribal origin. Guilds and fraternities were at the same time spiritual and professional organizations. An open attitude of cooperation increasingly became an asset and a general human quality, that is, part of the public mindset: civility.

The German Reformation: after the theses of Luther in 1517 the German princes were in support of the new movement for Reformation. One of the important claims of Martin Luther was that every believer should be free in his and her own conscience, standing directly in front of God as responsible without being dependent on the mediation of the church. Also the Lutheran princes claimed that same right, so that they took over the authority over Canon law from the church, albeit on the one condition, that they should also orient their consciences on the gospel, which practically meant, orient themselves towards the theological faculties dispersed over the country, for spiritual guidance. Monks and nuns broke away from the monastries and freely exercised different professions. The freedom of conscience and a professional attitude at farmer homesteads or bakeries, shoemakers etc. became a characteristic of the professions in Germany. Conscientiousness implies a combination of freedom and responsibility. Up to our time this professionalism in Germany leads to high quality products.

The British parliamentary revolution: the lower nobility followed the Calvinist version of the Reformation, which put the right to reform also in the hands of the lower authorities, city councils, or any social group (at least when necessary), that was well-organized and capable to organize church and society from the bottom up. The Commons, the lower nobility in Britain, conquered parliament in a decisive revolutionary change brought about in 1688 , the Glorious Revolution. Their team spirit, which they already exercised during the revolution and which made them win the revolution became an important and lasting characteristic of the British Parliament and of British society. This public spirit remained a strong human quality of the British involving many bottom-up organizations, foundations, NGOs for self-organization and for meeting the needs of society.

The French Revolution: free citizens without an office, just individuals, put an end to the "artificial" hierarchical rule of the nobility and the king with a claim of being just rational and natural and secular. National unification and public opinion were paramount values in governance and public life. The passion of public opinion drove the revolution forward and became a national character trait.

The Russian Revolution: cool calculation of the needs of the proletarians and cool treatment of all the territories of the USSR as one big factory for production by means of five-year plans to which and all and everything was subject has become a lasting characteristic of the nation.

The World Wars: the upheaval of the world wars confronted the nations with the fact that in their competition they had become little more than forces of nature clashing with each other. The only way out has become more intense negotiation, responsibility, in other words: speech itself had to be exercised with a new intensity and has become more pronounced. Besides being a medium for information language increasingly developed into a means of mutual interpretation and interpenetration of different and opposing values. We are in the middle of this process even though we also live under the heavy impact of the French and the Russian Revolution. Everywhere we hear the language of selfdestination (France), comprehensive planning (Russian), but also of dialogue and responsibility towards each other and towards the (vulnerable) future, which actually represents the spiritual heritage of the world wars. It is language, living speech, that needs to establish a polyglot peace: different contributions merge with each other and marry to each other. They have to find the when and where of the relevance of each of them, find the right alternation, modify each other, rescue each other, replace each other, support each other. The global postwar order is not merely a sort of mathematical system that includes or doesn't include some or other people from its planning (as Levinas tends to describe it), but more so an order in which different values, human qualities, and concomitant institutions support each other and talk to each other in a continuous and living 
process. Such is the vision of RosenstockHuessy, which he not only put forward in his book about the European Revolutions, but also in his later work on the emergence of one world society, the Soziologie [Rosenstock-Huessy 1956, Rosenstock-Huessy 1958].

\section{Conclusion: moral neighborhood and planetary pioneering}

The message of the world wars and of the post world-war situation is clear: we are stuck with each other and we will have to accept responsibility for each other. The language philosophy of Rosenstock-Huessy and later after the second world war Levinas prepares us for that new situation. The primary fact of our existence is that we live morally speaking as neighbors of each other and that as neighbors we have to accept responsibilities we didn't ask for. The world has become one village and the consequences of an economic crisis or a military conflict in one part of the world are immediately felt in the rest of the world. And although we tend to behave as if that is not yet true, we are overtaken by the facts themselves and one of those facts is the COVID-19 situation.

Therefore it is not merely by well understood self-interest that we have to take responsibility for each other. First it is a primary moral fact. It is important to emphasize this sequence, because without recognition of this moral fact and of the new rule of language as connected to the grammatical method, concrete measures and policy proposals will not be taken seriously. The urgency, that is, in terms of the grammatical method, the imperative that drives the change should first be recognized. We may not be in a position to solve the COVID-19 crisis if we do not manage to share the vaccines with the whole world population. If the coronavirus circulates in a substantial part of the world population there is a high risk of genetic modification leading to a new type of corona virus that is resistant to the existing vaccines. That might easily lead to a situation in which global society has to go through the complete Corona crisis for a second time. The way the emerging worldwide society deals with the Corona situation also is a warming up for the real crisis that is coming towards us, global warming and climate crisis.
Secondly our different moral and cultural qualities, codes, mindsets, - they need to be understood as contributions. Here a reminder of Hans Ehrenberg is in place: our specializations, culturally, religiously speaking and morally speaking should be tuned towards each other. Not one of them is absolutely right in itself, but all of them need to find the right timing for them to be true. The absolute truths of the past in that sense need to become denominations, voices in a choir. That also implies that our differences may be more interesting than some common denominator. Like a father and a mother need to fine-tune their different contributions towards each other, but not erase their differences, the care of the mother, the strength of the father, in order to raise their children towards maturity, the different traditions that constitute the richness of this world have to find the right order and sequence and alternation.

It may be clear that the way forward cannot be opened merely by representatives of world governments. One cannot expect nation states and power blocs to pioneer new futures. Instead, small groups have to pioneer their way forward in order to clear the thicket around us and find a road that can also be followed by larger numbers. These can be small enterprises, NGOs, civil initiatives, bottom-up networks all over the world [Kroesen 2000]. Our world is endangered by mythical collectivisms of all kinds: uprooted people always try to secure their belongingness even if it means they identify with dangerous political movements and so-called strong leaders. But small groups that recognize their differences may create a different atmosphere and draw others with them. Like the original tribes did such groups have to pioneer their way forward, they are not certain where they are going. The old tribes had to move in space, our modern entrepreneurial and pioneering tribes have to move through time: experiment with new ways of cooperation while also re-connecting to the past. They are the creative minorities that lead the way. Concretely that means they experiment by means of the grammatical method: they are the ones who take a new imperative seriously and follow proposals and counterproposals. Thanks to their substitution, and the sacrifice connected to it, a transubstantiation takes place of the heritage of many cultures into new responsibilities and human types. Their pioneering and courage and their responsibility for the others creates the 
support base for institutional change in the end. Only in this way the nations and cultures of this world will live together in a space that is otherwise too small. The COVID-19 situation "forces" us to take the next step in that movement.

\section{REFERENCES}

Ehrenberg H., 1920. Die Heimkehr des Ketzers - eine Wegweisung. Würzburg, Patmos Verlag.

Kroesen J.O., Darson R., Ndegwah J.D., 2020. CrossCultural Entrepreneurship and Social Transformation: Innovative Capacity in the Global South. Saarbrücken, Lambert.

Leenman B., 2016. Als God stukloopt - De maatschappij als erfgenaam van de kerk. Vught, Skandalon.

Levinas E., 1961. Totalité et Infini. Den Haag, Nijhoff. Levinas E., 1963. Difficile Liberté. Paris, Albin Michel.

Levinas E., 1973. Autrement qu'être. Den Haag, Nijhoff.
Rosenstock-Huessy E., 1920. Die Hochzeit des Krieges und der Revolution. Würzburg, Patmos Verlag.

Rosenstock-Huessy E., 1926. Vom Industrierecht Reschtssystematische Fragen. Berlin, Herman Sack.

Rosenstock-Huessy E., 1956-1958. Soziologie. In 2 $B d$. Stuttgart, Kohlhammer.

Rosenstock-Huessy E., 1963. Angewandte Seelenkunde. Die Sprache des Menschengeschlecht. Bd. I. Heidelberg, Verlag Lambert, Schneider.

Rosenstock-Huessy E., 1970. Speech and Reality. Norwich, Argo Books.

Rosenstock-Huessy E., 1989. Die Europäischen Revolutionen und der Charakter der Nationen. Moers, Brendow.

Rosenstock-Huessy E., 1993. Out of Revolution Autobiography of Western Man. New York, Argo Books.

Rosenzweig F., 1976. Der Stern der Erlösung. Den Haag, Nijhoff.

Winkler A., 2009. Geschichte des Westens von den Anfängen in der Antike bis zum 20. Jahrhundert. München, C.H.Beck.

\section{Information About the Author}

O. Kroesen, PhD, Assistant Professor in Cross-Cultural Management and Entrepreneurship, Business Ethics, Delft Center for Entrepreneurship, Delft University of Technology, PO Box 5, 2600 AA Delft, The Netherlands, J.O.Kroesen@TUDelft.nl, https://orcid.org/0000-0002-3054-1639

\section{Информация об авторе}

Отто Кройзен, доктор философии, профессор [в области] кросс-культурного менеджмента и предпринимательства, деловой этики, Делфтский центр предпринимательства, Делфтский технологический университет, РО Вох 5, 2600 АА г. Делфт, Нидерланды, J.O.Kroesen@TUDelft.nl, https://orcid.org/0000-0002-3054-1639 